๑Copyright 2021 by Turkish Society of Hematology

Turkish Journal of Hematology, Published by Galenos Publishing House

\title{
REPLY FROM THE AUTHORS
}

We have reviewed the commentary by Sookaromdee and Wiwanitkit and our reply is as follows.

We observed a patient with long-term multiple myeloma (MM) and an infrequent infection with Cystoisospora belli [1]. An intestinal-type chronic diarrhea was the only symptom contributing to the diagnosis. We wished to emphasize awareness of $C$. belli infection in MM patients. Sookaromdee and Wiwanitkit are of the same opinion as they mentioned the importance of $C$. belli infection in MM patients and emphasized that recommendations should be developed based on regional characteristics, especially in relation to poor hygiene conditions. They also cited an original study reported from Brazil to demonstrate that the infection could be observed in this patient population [2]. The mentioned study included 47 hematological malignancy patients and evaluated the infectious complications in patients who underwent autologous stem cell transplantation. The number of MM patients was 29. The study did not specify infectious agents according to primary diagnosis. The only result given in that study that might be pertinent for C. belli infection was that the authors observed 7 coccidia cases.
Coccidia subgroups were not defined. For that reason, we did not cite that study in our original manuscript. Indeed, our aim was similar to that of Sookaromdee and Wiwanitkit; when treating MM patients from variable hygienic backgrounds with the complication of diarrhea, $C$. belli should be considered. Thus, the letter above supports our original argument.

Tarık Onur Tiryaki, Kadir Uluç Anıl, Melek Büyük, Ahmet Yasir Yıldırım, Alp Atasoy, Aslı çiftçibaşı Örmeci, Sevgi Kalayoğlu Beşışık

\section{References}

1. Tiryaki TO, Anıl KU, Büyük M, Yıldırım AY, Atasoy A, Örmeci AC, Beşışık SK. Prolonged severe watery diarrhea in a long-term myeloma survivor: an unforeseen infection with Cystoisospora belli. Turk J Hematol 2021;38:171173.

2. de Castro MD, Chebli JM, Costa ப, Alves KRL, Atalla A, Neto AEH. Infectious diarrhea in autologous stem cell transplantation: high prevalence of coccidia in a South American center. Hematol Transfus Cell Ther 2018:40:132-135.

\section{Lenalidomide Combined with Interferon $\alpha-1 b$ and Interleukin-2 in the Treatment of 21 Cases of Acute Myeloid Leukemia}

\author{
Yirmi Bir Akut Myeloid Lösemi Olgusunda Interferon $\alpha-1 b$ ve Interlökin-2 ile Birlikte \\ Lenalidomid Tedavisi
}

(1) Cheng Cheng*, (1) Ruihua Mi*, (1) Dongbei Li, (1) Lin Chen, (1) Xudong Wei

Affiliated Tumor Hospital of Zhengzhou University, Henan Cancer Hospital, Department of Hematology, Zhengzhou, China

*These authors contributed equally to this work.

\section{To the Editor,}

The prognosis of patients with refractory/relapsed acute myeloid leukemia (R/R AML) is extremely poor and the longterm survival rate is less than $10 \%$. Minimal residual disease (MRD) is an important independent prognostic indicator of $A M L$, indicating a higher risk of recurrence; thus, it is vital for the prognosis of patients to eliminate MRD $[1,2]$. Our center previously used thalidomide combined with interferon $\alpha-1 b$ (IFN $\alpha-1 b$ ) and interleukin-2 (IL-2) in the treatment of R/R AML and the total effective rate was 50\% $[3,4]$. We further optimized the treatment plan, adjusted thalidomide to lenalidomide, and applied it for 21 patients with R/R AML or MRD.

All patients were treated with lenalidomide combined with the IFN $\alpha-1 b$ and IL-2 regimen. The specific treatment plan was as follows: oral administration of lenalidomide capsule, 
10-25 mg, every night; IFN- $\alpha 1 \mathrm{~b}, 60 \mu \mathrm{g}$; and IL-2, 1,000,000 U subcutaneous injection, once every other day. Each treatment cycle lasted 4 weeks. This retrospective analysis was approved by the Institutional Review Board of Henan Cancer Hospital.

Among 17 patients with R/R AML, 7 patients had complete remission (CR), 2 had CR with incomplete recovery of blood cells (CRi), and 8 had no remission. One patient in the low-risk group achieved $C R$, while the remission rate in the intermediate-risk group and high-risk group was 57.1\% (4/8) and 50\% (4/8), respectively. Of 3 patients with TET2 mutations, 2 patients achieved remission; 6 patients with FLT3-ITD/TKD mutations were given sorafenib at the same time and 3 patients achieved remission. Particularly, among the 4 MRD-positive patients with remission of AML, the MRD of 3 patients was lower than before and the MRD of 1 patient was higher than before. These patients' clinical data are presented in Table 1. The total effective rate $(\mathrm{CR}+\mathrm{CRi}+\mathrm{MRD}$ decreased) of 21 patients was $57.1 \%$. No treatment-related deaths occurred. The median overall survival time of the 21 patients was 26 months (9-89 months), and the 3-year survival rate reached $42.9 \%$. Among patients with effective application of this regimen, the duration of relief ranged from 2 to $28+$ months.

IFN can directly kill AML by inhibiting growth-promoting cytokines, inducing apoptosis, and inhibiting cell proliferation. Meanwhile, it is possible to indirectly target AML cells through the immunostimulatory effects of interferon on dendritic cells, T-cells, and natural killer (NK) cells $[5,6]$. IL-2 increases the proliferation and activity of cytotoxic T-cells, NK-cells, and killer cells activated by lymphokines. It can also promote the secretion of antibodies and interferon to play an anti-tumor role [7]. Lenalidomide promotes tumor cell apoptosis by inhibiting the secretion of tumor necrosis factor $\alpha, I L-1$, and IL-12. It also produces an anti-tumor effect by inhibiting the secretion of overexpressed vascular endothelial growth factor $[8,9,10]$.

The combination of lenalidomide, IFN $\alpha-1 \mathrm{~b}$, and IL-2 showed improvements in efficacy and safety profiles as compared to monotherapy among patients with $R / R A M L$, and especially in the elimination of MRD, and it may become a promising treatment regimen.

Keywords: Acute myeloid leukemia, Refractory/relapsed, Minimal residual disease, Lenalidomide, Interferon $\alpha-1 b$, Interleukin-2

Anahtar Sözcükler: Akut myeloid lösemi, Dirençli/nüks, Minimal kalıntı hastalık, Lenalidomid, İnterferon $\alpha-1 b$, İnterlökin-2

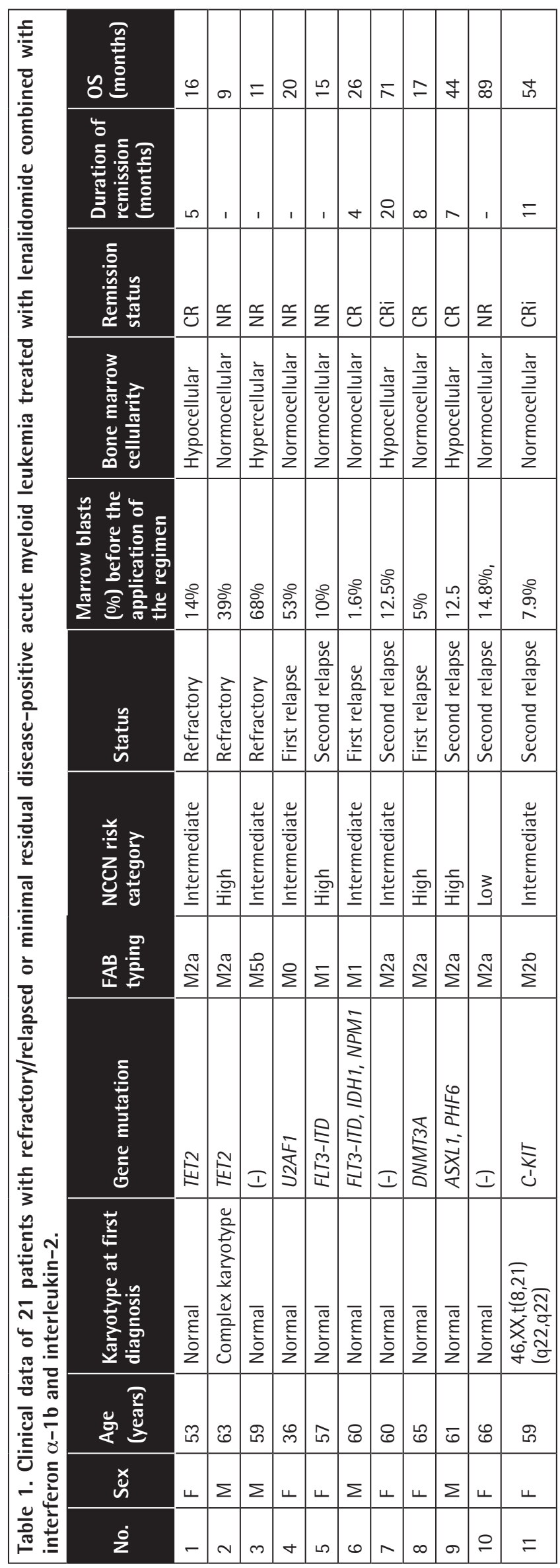




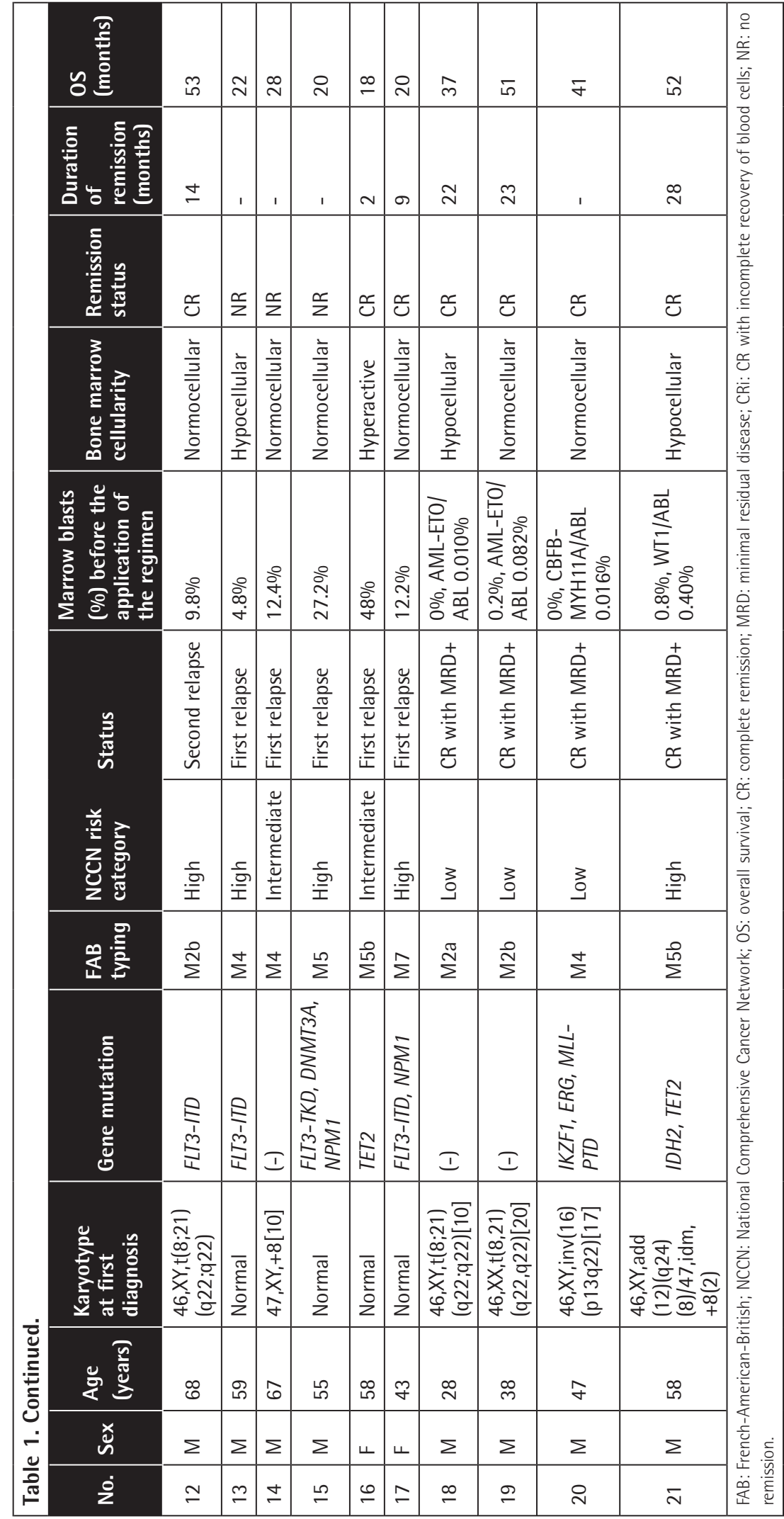

- Copyright 2021 by Turkish Society of Hematology Turkish Journal of Hematology, Published by Galenos Publishing House

\section{Authorship Contributions}

Concept: C.C., R.M. D.L., L.C., X.W.; Writing: C.C., R.M.

Conflict of Interest: No conflict of interest was declared by the authors.

Financial Disclosure: This study was supported by the Henan Science and Technology Research Project (No. 192102310056; No. 202102310053).

\section{References}

1. Dohner $H$, Weisdorf DJ, Bloomfield CD. Acute myeloid leukemia. N Engl J Med 2015;373:1136-1152.

2. Schuurhuis GJ, Heuser $M$, Freeman $S$, Béné $M-C$, Buccisano F, Cloos J, Grimwade D, Haferlach T, Hills RK, Hourigan CS Jorgensen JL, Kern W, Lacombe F, Maurillo L, Preudhomme $C$, van der Reijden BA, Thiede C, Venditti A, Vyas P, Wood BL, Walter RB, Döhner K, Roboz GJ, Ossenkoppele GJ. Minimal/ measurable residual disease in AML: a consensus document from the European LeukemiaNet MRD Working Party. Blood 2018;131:1275-1291.

3. Wei XD, Ai H, Mi RH, Chen L, Yuan FF, Hao QM, Yin OS Wang $P$, Song YP. Thalidomide combined with interferon and interleukin-2 in treatment of relapsed or refractory acute myelogenous leukemia. Zhonghua Nei Ke Za Zhi 2016;5511:875-877

4. Mi RH, Chen L, Wei XD, Yin OS, Wang MF, Liang $\amalg$, Yuan FF, Li MJ, Ji XJ, Song YP. Therapeutic effect of combined use of interferon alpha-1b, interleukin-2 and thalidomide on reversing minimal residual disease in acute myeloid leukemia. Zhonghua Xue Ye Xue Za Zhi 2019;40:111-116.

5. Anguille $\mathrm{S}$, Lion $\mathrm{E}$, Willemen $\mathrm{Y}$, Van Tendeloo VF, Berneman $Z N$, Smits EL. Interferon- $\alpha$ in acute myeloid leukemia: an old drug revisited. Leukemia 2011;25:739-748.

6. Ferrantini M, Capone I, Belardelli F. Interferon- $\alpha$ and cancer: mechanisms of action and new perspectives of clinical use. Biochimie 2007;89:884-893.

7. Inamoto $Y$, Fefer $A$, Sandmaier BM, Gooley TA, Warren EH, Petersdorf SH, Sanders JE, Storb RF, Appelbaum FR Martin PJ, Flowers ME. A phase I/II study of chemotherapy followed by donor lymphocyte infusion plus interleukin-2 for relapsed acute leukemia after allogeneic hematopoietic cell transplantation. Biol Blood Marrow Transplant 2011;17:1308-1315.

8. Skarbnik AP, Goy AH. Lenalidomide for mantle cell lymphoma. Expert Rev Hematol 2015;8:257-264.

9. Ruan J, Martin P, Shah B, Schuster SJ, Smith SM, Furman RR, Christos P, Rodriguez A, Svoboda J, Lewis J, Katz O, Coleman M, Leonard JP. Lenalidomide plus rituximab as initial treatment for mantle-cell lymphoma. N Engl J Med 2015;373:1835-1844.

10. Luo J, Gagne JJ, Landon J, Avorn J, Kesselheim AS Comparative effectiveness and safety of thalidomide and lenalidomide in patients with multiple myeloma in the United States of America: a population-based cohort study. Eur J Cancer 2017;70:22-33. 